\title{
DIFFERENCES IN METALLIC CONTENT BETWEEN MARINE VERTEBRATES AND INVERTEBRATES LIVING IN OCEANIC ISLANDS
}

\author{
Enrique Lozano-Bilbao*, José María Espinosa**, \\ Gonzalo Lozano*, Arturo Hardisson ${ }^{* * *}$, \\ Carmen Rubio $^{* * *}$, Dailos González Weller’, \\ Soraya Paz ${ }^{* * *}$, Ángel J. Gutiérrez ${ }^{* * *}$
}

\section{Abstract}

The metallic content in each class of organism varies in different ways, depending on metabolism, habitat behavior, and where it is found in the trophic network. In this study, 845 specimens of different types of marine invertebrate and vertebrate organisms of the Canary Islands have been analyzed, of them the content of 20 metals and trace elements has been analyzed (Al, B, Ba, Ca, Cd, Co, Cr, Cu, Fe, K, Li, Mg, Mn, Mo, Na, Ni, Pb, $\mathrm{Sr}, \mathrm{V}$ and $\mathrm{Zn}$ ) in $\mathrm{mg} / \mathrm{kg}$. In the PCoA analyzes it is clearly seen how the invertebrate and vertebrate organisms are separated according to their metallic content, there being significant differences between these two groups in each of the trace elements and metals. Invertebrate species having the highest concentration in all metals and trace elements, may have a higher concentration of metals than vertebrates because they have a very fast growth, and with it a high metabolic rate that causes higher concentrations of the elements to bioaccumulate.

KEYwORDS: vertebrate, invertebrate, trace elements, metal.

\section{DIFERENCIAS EN EL CONTENIDO EN METALES DE LOS VERTEBRADOS E INVERTEBRADOS MARINOS QUE VIVEN EN ISLAS OCEÁNICAS}

\section{RESUMEN}

El contenido metálico en cada clase de organismo varía de diferentes formas; según el metabolismo, el hábitat y el lugar de la red trófica en que se encuentre. En este estudio se han analizado 845 ejemplares de diferentes tipos de organismos vertebrados e invertebrados marinos de Canarias, de ellos se ha analizado el contenido de 20 metales y elementos traza (Al, B, Ba, Ca, Cd, Co, Cr, Cu, Fe, K, Li, Mg, Mn, Mo, Na, Ni, Pb, Sr, V y Zn) en $\mathrm{mg} / \mathrm{kg}$. En los análisis de PCoA se observa claramente cómo los organismos invertebrados y vertebrados se separan según su contenido metálico, existiendo diferencias significativas entre estos dos grupos en cada uno de los elementos traza y metales estudiados. Las especies de invertebrados tienen la mayor concentración en todos los metales y oligoelementos, pueden tener una mayor concentración de metales que los vertebrados debido a que tienen un crecimiento muy rápido, y con ello una alta tasa metabólica que hace que se bioacumulen concentraciones más altas de los elementos.

Palabras Clave: vertebrados, invertebrados, elementos traza, metal. 


\section{INTRODUCTION}

The Animalia kingdom comprises two large groups, vertebrates and invertebrates, which are very varied internally. Vertebrates represent a small group in the animal kingdom, although due to their location on the trophic scale, they play a key role for life on Earth (Fischer et al., 2012).

Although we find cartilage tissue in different organisms of the animal kingdom, bone, dentin and enamel are exclusive tissues of vertebrates (Grillner, 2018; Hedges, 1998; Kumar et al., 2017; Roach et al., 2005). The main constituent mineral of hard tissues is hydroxyapatite, a form of calcium phosphate (Kawasaki and Weiss, 2003; Kikuchi et al., 2004; Pezzotti et al., 2016). The shells and other hard tissues of invertebrates are made of a different substance, carbonate.

Invertebrates represent many animals on Earth, and they do not possess a notochord or dorsal cord, nor a vertebral column, nor an articulated internal skeleton. In this set $95 \%$ of the known living species are found, between 1.7 and 1.8 million species (Brittain and Eikeland, 1988; Kurtz and Franz, 2003; Ratcliffe et al., 1985). These differences cause them to have different metabolic rates, being higher in invertebrates that have a much shorter life expectancy and that have large amounts of nutrients for their growth and development, having fewer detoxification mechanisms, therefore accumulating toxins and other xenobiotics in the body (Brockington and Clarke, 2001; Heikens et al., 2001; Mason et al., 2000; Livingstone, 1991).

Trace elements and metals are incorporated into the marine trophic network in various ways, such as the anthropic of discharges from the coast to the ocean, runoff in plantation areas, contamination by factories, etc. Naturally, we find the effects of upwelling that ascends nutrients and elements from the lower layers of the ocean, sandstorms from deserts that enrich the ocean, etc. (Afandi et al., 2018; Lozano-Bilbao et al., 2019b, 2020d; Ruilian et al., 2008; Qing et al., 2015).

All organisms have evolved and developed detoxification techniques for compounds that are harmful to your body, either the accumulation of these elements in the body such as in fat or in organs such as the hepatopancreas in molluscs and arthropods or the liver in most vertebrates. There are mechanisms of excretion of harmful substances that depend on the chelating substances that organisms can create (Bustamante et al., 2008; Lozano-Bilbao et al., 2020b, 2019a; Raimundo et al., 2005; Rainbow and Luoma, 2011; Saénz de Rodrigáñez et al., 2005). The main

* Departamento de Biología Animal y Edafología y Geología, Unidad Departamental de Ciencias Marinas, Universidad de La Laguna, 38206 La Laguna, Santa Cruz de Tenerife, Spain.

** Fundación del Sector Público Estatal Observatorio Ambiental Granadilla (Unidad Técnica), 38001, Santa Cruz de Tenerife, Spain.

*** Departamento de Obstetricia y Ginecología, Pediatría, Medicina Preventiva y Salud Pública, Toxicología, Medicina Legal y Forense y Parasitología. Área de Toxicología, Universidad de La Laguna, 38200 La Laguna, Santa Cruz de Tenerife, Spain.

- Servicio Público Canario de Salud, Laboratorio Central, Santa Cruz de Tenerife, Spain. Corresponding author: lozaenr@gmail.com. 
objective of this research is to verify the possible group (invertebrate and vertebrate) by metallic content and trace elements of species.

\section{MATERIAL AND METHODS}

A total of 845 samples of 20 different species were collected from Canary

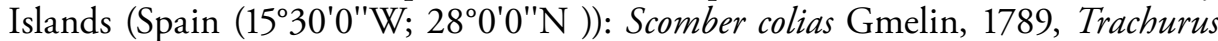
picturatus (Bowdich, 1825), Sardina pilchardus (Walbaum, 1792), Serranus cabrilla (Linnaeus, 1758), Mullus surmuletus (Linnaeus, 1758), Diplodus sargus (Linnaeus, 1758), Sarpa salpa (Linnaeus, 1758), Chelon labrosus (Risso, 1827), Sparisoma cretense (Linnaeus, 1758), Anemonia sulcata (Pennant, 1777), Sepia officinalis Linnae, 1758, Octopus vulgaris Cuvier, 1797, Loligo vulgaris Lamarck, 1798, Patella aspera Röding, 1798, Patella candei crenata D'Orbigny, 1840, Palaemon elegans Rathke, 1837, Plesionika narval (Fabricius, 1787), Physeter macrocephalus Linnae Stenella frontallis (Cuvier, 1829) and Tursiops truncatus (Montagu, 1821). Part of this data was used in (Lozano-Bilbao et al., 2020a). In the present study, live verbs were not manipulated, the samples were taken from stranded animals (cetaceans) and fish markets (fish).

\section{Treatment of The SAMPLeS}

The sample consisted of a portion of muscle between 10-15 g. The samples were dried in an oven at a temperature of $70^{\circ} \mathrm{C}$ for 24 hours. Subsequently, they were incinerated in a muffle-furnace for 48 hours at $450^{\circ} \mathrm{C} \pm 25^{\circ} \mathrm{C}$, until obtaining white ashes.

Obtained the white ashes, they were filtered with a $1.5 \% \mathrm{HNO}_{3}$ solution until $25 \mathrm{~mL}$ of total volume for the subsequent determination of the metallic content (Al, B, Ba, Ca, Cd, Co, Cr, Cu, Fe, K, Li, Mg, Mn, Mo, Na, Ni, Pb, Sr, Vy Zn) by Inductively Coupled Plasma Optical Emission Spectrometry (ICP-OES) (LozanoBilbao et al., 2018b).

\section{STATISTICAL ANALYSIS}

In order to study existence of differences in the content and relative composition of metals and trace metals among the analyzed samples, a statistical analysis was performed, using a distance-based permutational multivariate analysis of variance (PERMANOvA) with Euclidean distances (Anderson and Braak, 2003).

A one-way design was used with the fixed factor of "Organism type" with two levels of variation:

Vertebrate $=$ Scomber colias, Trachurus picturatus, Sardina pilchardus, Physeter macrocephalus, Stenella frontallis, Tursius truncatus, Serranus cabrilla, Mullus surmuletus, Diplodus sargus, Sarpa salpa, Chelon labrosus and Sparisoma cretense. 


\begin{tabular}{|c|c|c|c|c|c|c|c|}
\hline \multirow[b]{3}{*}{$\mathrm{Al}$} & \multicolumn{7}{|c|}{$\begin{array}{l}\text { TABLE 1. MEAN METAL AND TRACE ELEMENT CONCENTRATIONS (MG/KG), } \\
\text { STANDARD DEVIATION AND STATISTICAL PARAMETER OF THE PAIR TEST } \\
\text { (PERMANOVA) BETWEEN INVERTEBRATE AND VERTEBRATE }\end{array}$} \\
\hline & \multicolumn{3}{|c|}{ VERTEBRATE } & \multicolumn{3}{|c|}{ INVERTEBRATE } & \multirow{2}{*}{$\begin{array}{c}\text { VERTEBRATE VS. INVERTEBRATE } \\
0.001^{*}\end{array}$} \\
\hline & 4.060 & \pm & 3.342 & 5.828 & \pm & 5.943 & \\
\hline $\mathrm{B}$ & 0.189 & \pm & 0.188 & 0.871 & \pm & 1.040 & $0.001^{*}$ \\
\hline $\mathrm{Ba}$ & 0.208 & \pm & 0.191 & 0.417 & \pm & 0.534 & $0.001^{*}$ \\
\hline $\mathrm{Ca}$ & 696.853 & \pm & 935.076 & 797.231 & \pm & 1006.970 & $0.001^{*}$ \\
\hline $\mathrm{Cd}$ & 0.040 & \pm & 0.112 & 0.531 & \pm & 0.819 & $0.001^{*}$ \\
\hline Co & 0.006 & \pm & 0.006 & 0.022 & \pm & 0.027 & $0.001^{*}$ \\
\hline $\mathrm{Cr}$ & 0.157 & \pm & 0.274 & 0.207 & \pm & 0.258 & $0.001^{*}$ \\
\hline $\mathrm{Cu}$ & 0.891 & \pm & 0.613 & 1.877 & \pm & 2.073 & $0.001^{*}$ \\
\hline $\mathrm{Fe}$ & 13.352 & \pm & 25.180 & 27.332 & \pm & 37.495 & $0.001^{*}$ \\
\hline $\mathrm{K}$ & 2074.230 & \pm & 759.03 & 935.876 & \pm & 790.995 & $0.001^{*}$ \\
\hline $\mathrm{Li}$ & 0.494 & \pm & 0.458 & 0.587 & \pm & 0.665 & $0.001^{*}$ \\
\hline $\mathrm{Mg}$ & 281.871 & \pm & 84.911 & 387.106 & \pm & 450.859 & $0.001^{*}$ \\
\hline $\mathrm{Mn}$ & 0.255 & \pm & 0.407 & 0.494 & \pm & 0.573 & $0.001^{*}$ \\
\hline Mo & 0.013 & \pm & 0.023 & 0.068 & \pm & 0.078 & $0.001^{*}$ \\
\hline $\mathrm{Na}$ & 671.279 & \pm & 285.698 & 1333.420 & \pm & 1062.840 & $0.001^{*}$ \\
\hline $\mathrm{Ni}$ & 0.171 & \pm & 0.434 & 0.366 & \pm & 0.755 & $0.001^{*}$ \\
\hline $\mathrm{Pb}$ & 0.059 & \pm & 0.074 & 0.316 & \pm & 0.637 & $0.001^{*}$ \\
\hline $\mathrm{Sr}$ & 1.455 & \pm & 1.834 & 1.870 & \pm & 1.716 & $0.001^{*}$ \\
\hline $\mathrm{V}$ & 0.108 & \pm & 0.547 & 0.179 & \pm & 0.216 & $0.001^{*}$ \\
\hline $\mathrm{Zn}$ & 6.970 & \pm & 5.888 & 5.438 & \pm & 4.126 & $0.001^{*}$ \\
\hline
\end{tabular}

Invertebrate = Loligo vulgaris, Anemonia sulcata, Sepia officinalis, Octopus vulgaris, Patella aspera, Patella candei crenata, Palaemon elegans and Plesionika narval.

Relative dissimilarities among the groups were studied using a principal coordinate analysis (PCoA) where metals that best explained data variability were represented as vectors.

In all analyzes, 9999 permutations of exchangeable units and a posteriori pairwise comparisons were used to verify the differences between the levels of the significant factors ( $\mathrm{p}$-value $<0.01$ ) (Anderson, 2004). The statistical packages PRIMER 7 \& PERMANOVA + v.1.0.1 were used for the statistical analyzes.

\section{RESULTS}

Table 1 shows the metal average concentration $(\mathrm{mg} / \mathrm{kg})$ by vertebrate and invertebrate species. $\mathrm{K}(2074 \pm 759 \mathrm{mg} / \mathrm{kg})$ level in vertebrates is higher than $\mathrm{K}(936 \pm 791 \mathrm{mg} / \mathrm{kg})$ in invertebrates. Levels of the other metals and trace elements stand out in invertebrates. 

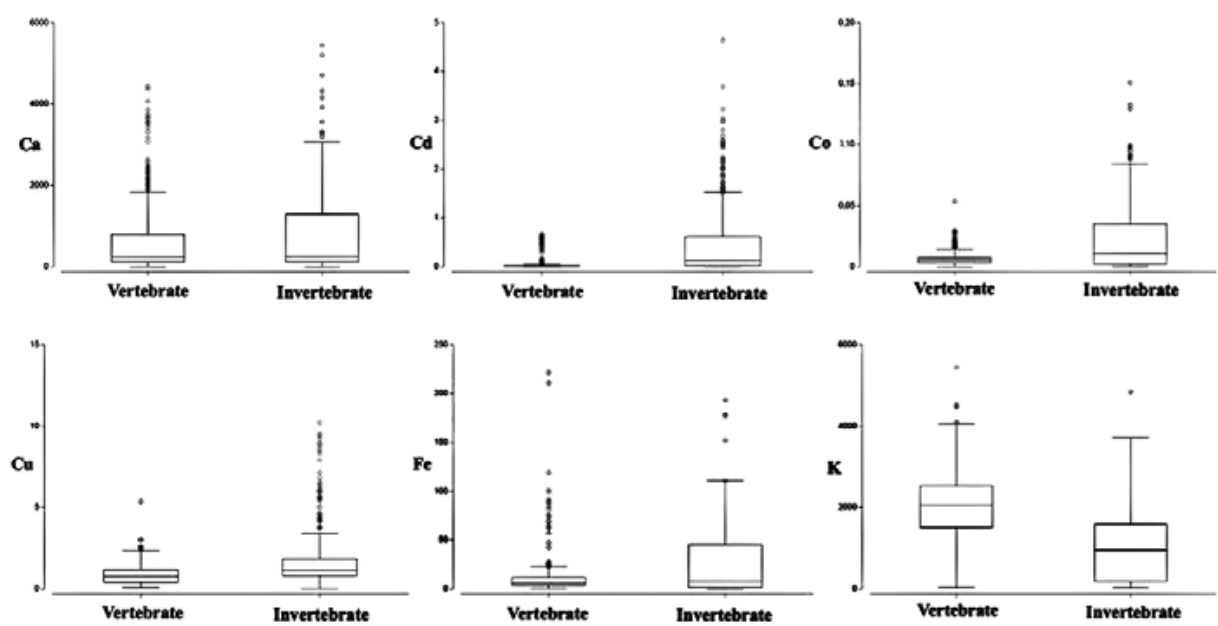

Figure 1. Boxplot graphs showing mean values for the metal contents, and minimum, maximum $\mathrm{mg} / \mathrm{kg}$ (w.w.), for each kind of organism.

According to the type of organism (vertebrates or invertebrates), PERMANOVA revealed significant differences in the content of trace elements and metals between vertebrates and invertebrates $(F=254.63 ; \mathrm{p}=0.001)$. The PERMANOVA results better explained the variability of the data for all metals and trace elements, since all presented significant differences, with invertebrates showing the highest concentration in all metals and trace elements except for $\mathrm{K}$ (fig. 1). These differences are clearly seen in the PCoA (fig. 2), in this graph it is observed how the vertebrate and invertebrate samples are clearly separated due to the content of metals and trace elements that they contain in the muscle.

\section{DISCUSSION}

The growing of marine vertebrate species, generally, is slowly than invertebrate species. This is due to the large resources that are required for the formation of the bones and organs (Golling et al., 2002; Naiche et al., 2005; Schier, 2003). Vertebrate organisms have more detoxification mechanisms than invertebrates, and like them, they have the liver, which is a storage organ for many toxins that regulates most of the chemical levels in the blood and excretes bile, which helps to break down fats and prepares them for later digestion and absorption. The liver acts processing the blood and separates in its components, balances them, and creates nutrients for the body to use. It also metabolizes substances present in the blood to make them easier for the body to use (Angulo, 2002; Brasch, 1980; Eastwood and Couture, 2002; Tal et al., 2017). 


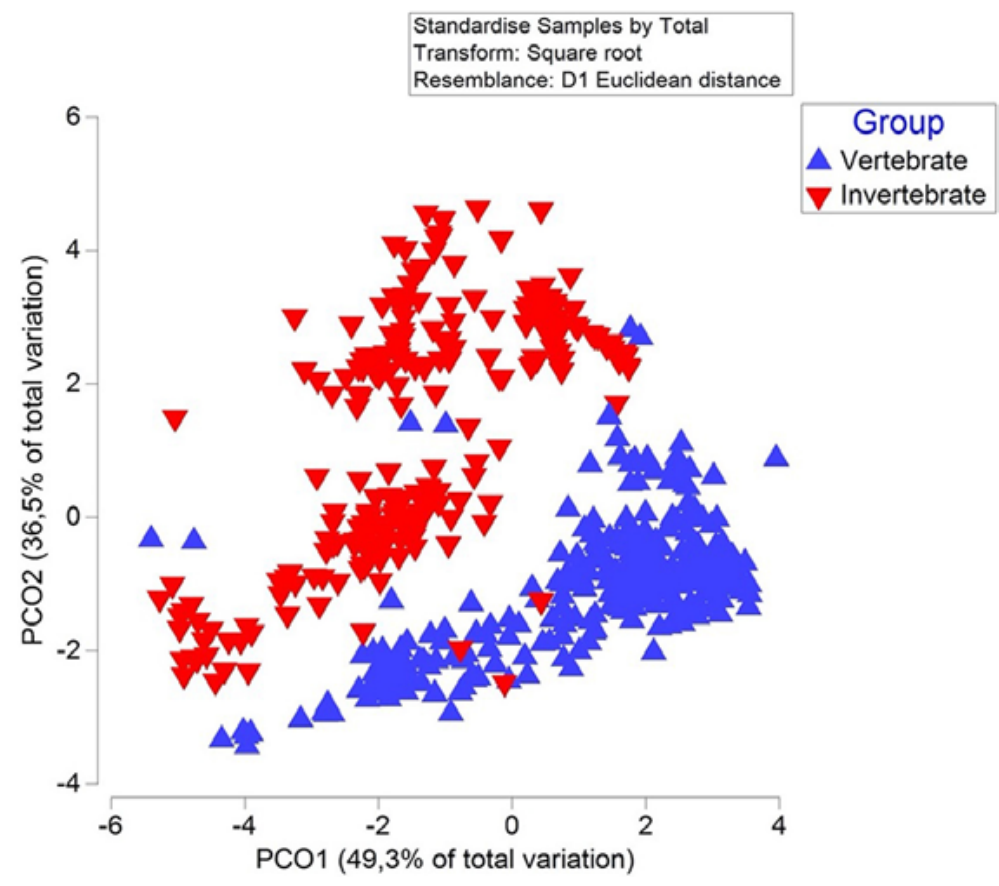

Figure 2. Principal coordinate analysis (PCoA) showing the first two axes (85.8\% of variability), based on Euclidean distances of square-root-transformed data and standardise of the metal and trace element content in the groups of vertebrate and invertebrate.

In general, the growing process of the marine invertebrate species is faster than vertebrate species and have a younger age period, presenting an accelerated growth in the first stages of life, this first phase being only an increase in mass with a very high metabolic rate and high nutrient requirements, while having few detoxification mechanisms so that high concentrations of toxins or heavy metals are not harmful to your health (Brockington and Clarke, 2001; Dallinger, 1994; Livingstone, 1991). Subsequent development involves physiological and structural changes in that mass (Bergquist et al., 2000; Brittain and Eikeland, 1988; Gallardo et al., 1997; Sutton et al., 2001). Therefore, invertebrates will bioaccumulate most of the metals and trace elements in the early stages of life, and it should be noted that different organisms, when growing very quickly, can reach large sizes and change the diet during growth as they can. this is the case of cephalopods (Gales et al., 1993; Lacoue-Labarthe et al., 2011; Piatkowski et al., 2002; Storelli et al., 2006). Mollusks and arthropods have developed the hepatopancreas, which acts as a warehouse for all these toxins and heavy metals, even so it is not enough and it has been observed in many studies that invertebrates such as anemones, cephalopods and crustaceans have high concentrations of metals and trace elements (Adami et al., 2002; Dallinger and Prosi, 1988; Fischer and Dietrich, 2000; Iijima et al., 1998), which in the case 
of cephalopods have very high $\mathrm{Cd}$ concentrations in muscle. (Bustamante et al., 2002; Carvalho et al., 2005; Lozano-Bilbao et al., 2020a; Storelli et al., 2006, 2005). For all this, they may have higher concentrations of metals and trace elements than vertebrate species. Invertebrate marine species are the most widely used as bioindicators of marine pollution; each species can be useful for more than one biomarker and by accumulating trace metals and elements more easily, it is easier to know the state of the ecosystem thanks to them (Dolenec et al., 2011; Li et al., 2019; Lionetto et al., 2003; Lozano-Bilbao et al., 2020c, 2018a).

Recibido: junio de 2021, ACEPTADo: octubre de 2021 


\section{REFERENCES}

Adami, G., Barbieri, P., Fabiani, M., Piselli, S., Predonzani, S. and Reisenhofer, E., 2002. Levels of cadmium and zinc in hepatopancreas of reared Mytilus galloprovincialis from the Gulf of Trieste (Italy). Chemosphere 48, 671-677. https://doi.org/https://doi.org/10.1016/ S0045-6535(02)00196-0.

Afandi, I., Talba, S., Benhra, A., Benbrahim, S., Chfiri, R., Labonne, M., Masski, H., LaË, R., Tito De Morais, L., Bekkali, M. and Bouthir, F.Z., 2018. Trace metal distribution in pelagic fish species from the north-west African coast (Morocco). Int. Aquat. Res. 10, 191205. https://doi.org/10.1007/s40071-018-0192-7.

Anderson, M. and Braak, C. Ter, 2003. Permutation tests for multi-factorial analysis of variance. J. Stat. Comput. Simul. 73, 85-113. https://doi.org/10.1080/00949650215733.

Anderson, M.R., 2004. The Resource for the Power Industry Professional. Proc. ASME POWER 32.

Angulo, P., 2002. Nonalcoholic Fatty Liver Disease. N. Engl. J. Med. 346, 1221-1231. https://doi. org/10.1056/NEJMra011775.

Bergquist, D.C., Williams, F.M. and Fisher, C.R., 2000. Longevity record for deep-sea invertebrate. Nature 403, 499-500. https://doi.org/10.1038/35000647.

Brasch, K., 1980. Endopolyploidy in vertebrate liver: An evolutionary perspective. Cell Biol. Int. Rep. 4, 217-226. https://doi.org/https://doi.org/10.1016/0309-1651(80)90077-6.

Brittain, J.E. and Eikeland, T.J., 1988. Invertebrate drift -A review. Hydrobiologia 166, 77-93. https://doi.org/10.1007/BF00017485.

Brockington, S. and Clarke, A., 2001. The relative influence of temperature and food on the metabolism of a marine invertebrate. J. Exp. Mar. Bio. Ecol. 258, 87-99. https://doi.org/ https://doi.org/10.1016/S0022-0981(00)00347-6.

Bustamante, P., Cosson, R.P., Gallien, I., Caurant, F. and Miramand, P., 2002. Cadmium detoxification processes in the digestive gland of cephalopods in relation to accumulated cadmium concentrations. Mar. Environ. Res. 53, 227-241. https://doi.org/https://doi. org/10.1016/S0141-1136(01)00108-8.

Bustamante, P., González, A.F., Rocha, F., Miramand, P., Guerra, A., 2008. Metal and metalloid concentrations in the giant squid Architeuthis dux from Iberian waters. Mar. Environ. Res. 66, 278-287. https://doi.org/10.1016/j.marenvres.2008.04.003.

Carvalho, M.L., Santiago, S., Nunes, M.L., 2005. Assessment of the essential element and heavy metal content of edible fish muscle. Anal. Bioanal. Chem. 382, 426-432. https://doi. org/10.1007/s00216-004-3005-3.

DAllinger, R., 1994. Invertebrate organisms as biological indicators of heavy metal pollution. Appl. Biochem. Biotechnol. 48, 27-31. https://doi.org/10.1007/BF02825356.

Dallinger, R. and Prosi, F., 1988. Heavy metals in the terrestrial isopod Porcellio scaber Latreille. II. Subcellular fractionation of metal-accumulating lysosomes from hepatopancreas. Cell Biol. Toxicol. 4, 97-109. https://doi.org/10.1007/BF00141289.

Dolenec, M., Žvab, P., Mihelčić, G., Lambaša Belak, Ž., Lojen, S., Kniewald, G., Dolenec, T. and RogAN ŠMUC, N., 2011. Use of stable nitrogen isotope signatures of anthropogenic organic matter in the coastal environment: The case study of the Kosirina Bay (Murter Island, Croatia). Geol. Croat. 64, 143-152. https://doi.org/10.4154/gc.2011.12. 
Eastwood, S. and Couture, P., 2002. Seasonal variations in condition and liver metal concentrations of yellow perch (Perca flavescens) from a metal-contaminated environment. Aquat. Toxicol. 58, 43-56. https://doi.org/https://doi.org/10.1016/S0166-445X(01)00218-1.

Fischer, J.D., Cleeton, S.H., Lyons, T.P. and Miller, J.R., 2012. Urbanization and the Predation Paradox: The Role of Trophic Dynamics in Structuring Vertebrate Communities. Bioscience 62, 809-818. https://doi.org/10.1525/bio.2012.62.9.6.

Fischer, W.J. and Dietrich, D.R., 2000. Pathological and Biochemical Characterization of Microcystin-Induced Hepatopancreas and Kidney Damage in Carp (Cyprinus carpio). Toxicol. Appl. Pharmacol. 164, 73-81. https://doi.org/https://doi.org/10.1006/taap.1999.8861.

Gales, R., Pemberton, D., Lu, C.C. and Clarke, M.R., 1993. Cephalopod diet of the Australian fur seal: Variation due to location, season and sample type. Mar. Freshw. Res. 44, 657-671.

Gallardo, W.G., Hagiwara, A., Tomita, Y., Soyano, K. and Snell, T.W., 1997. Effect of some vertebrate and invertebrate hormones on the population growth, mictic female production, and body size of the marine rotifer Brachionus plicatilis Müller. Hydrobiologia 358, 113-120. https://doi.org/10.1023/A:1003124205002.

Golling, G., Amsterdam, A., Sun, Z., Antonelli, M., Maldonado, E., Chen, W., Burgess, S., Haldi, M., Artzt, K., Farrington, S., Lin, S.-Y., Nissen, R.M. and Hopkins, N., 2002. Insertional mutagenesis in zebrafish rapidly identifies genes essential for early vertebrate development. Nat. Genet. 31, 135-140. https://doi.org/10.1038/ng896.

Grillner, S., 2018. Evolution: Vertebrate Limb Control over 420 Million Years. Curr. Biol. 28, R162-R164. https://doi.org/https://doi.org/10.1016/j.cub.2017.12.040.

Heikens, A., Peijnenburg, W.J.G. and Hendriks, A.J., 2001. Bioaccumulation of heavy metals in terrestrial invertebrates. Environ. Pollut. 113, 385-393. https://doi.org/https://doi. org/10.1016/S0269-7491(00)00179-2.

Iıjima, N., Tanaka, S. and Ota, Y., 1998. Purification and characterization of bile salt-activated lipase from the hepatopancreas of red sea bream, Pagrus major. Fish Physiol. Biochem. 18, 59-69. https://doi.org/10.1023/A:1007725513389.

KaWAsaki, K. and Weiss, K.M., 2003. Mineralized tissue and vertebrate evolution: The secretory calcium-binding phosphoprotein gene cluster. Proc. Natl. Acad. Sci. 100, 4060 LP -4065. https://doi.org/10.1073/pnas.0638023100.

Kikuchi, M., Iкомa, T., Itoh, S., Matsumoto, H.N., Koyama, Y., Takakuda, K., Shinomiya, K. and TANAKA, J., 2004. Biomimetic synthesis of bone-like nanocomposites using the self-organization mechanism of hydroxyapatite and collagen. Compos. Sci. Technol. 64, 819-825. https://doi.org/https://doi.org/10.1016/j.compscitech.2003.09.002.

Kumar, S. and Hedges, S.B., 1998. A molecular timescale for vertebrate evolution. Nature 392, 917-920. https://doi.org/10.1038/31927.

Kurtz, J. and Franz, K., 2003. Evidence for memory in invertebrate immunity. Nature 425, 37-38. https://doi.org/10.1038/425037a.

Lacoue-Labarthe, T., Réveillac, E., Oberhänsli, F., Teyssié, J.L., Jeffree, R. and Gattuso, J.P., 2011. Effects of ocean acidification on trace element accumulation in the early-life stages of squid Loligo vulgaris. Aquat. Toxicol. 105, 166-176. https://doi.org/10.1016/j. aquatox.2011.05.021.

Landis, M.J. and Schraiber, J.G., 2017. Pulsed evolution shaped modern vertebrate body sizes. Proc. Natl. Acad. Sci. 114, 13224 LP - 13229. https://doi.org/10.1073/pnas.1710920114. 
Li, J., Lusher, A.L., Rotchell, J.M., Deudero, S., Turra, A., Bråte, I.L.N., Sun, C., Shahadat Hossain, M., Li, Q., Kolandhasamy, P. and Shi, H., 2019. Using mussel as a global bioindicator of coastal microplastic pollution. Environ. Pollut. 244, 522-533. https:// doi.org/https://doi.org/10.1016/j.envpol.2018.10.032.

Lionetto, M.G., Caricato, R., Giordano, M.E., Pascariello, M.F., Marinosci, L. and Schettino, T., 2003. Integrated use of biomarkers (acetylcholinesterase and antioxidant enzymes activities ) in Mytilus galloprovincialis and Mullus barbatus in an Italian coastal marine area. Mar. Pollut. Bull. 46, 324-330. https://doi.org/10.1016/S0025326X(02)00403-4.

Livingstone, D.R., 1991. Organic Xenobiotic Metabolism in Marine Invertebrates BT - Advances in Comparative and Environmental Physiology: volume 7, in Houlihan, D.F., Livingstone, D.R., Lee, R.F. (eds.). Springer Berlin Heidelberg, Berlin, Heidelberg, pp. 45-185. https:// doi.org/10.1007/978-3-642-75897-3_2.

Lozano-Bilbao, E., Alcázar-Treviño, J. and Fernández, J.J., 2018a. Determination of $\delta 15 \mathrm{~N}$ in Anemonia sulcata as a pollution bioindicator. Ecol. Indic. https://doi.org/10.1016/j.ecolind.2018.03.017.

Lozano-Bilbao, E., Clemente, S., Espinosa, J.M., Jurado-Ruzafa, A., Lozano, G., Raimundo, J., Hardisson, A., Rubio, C., GonzÁlez-Weller, D., Jiménez, S. and Gutiérrez, Á.J., 2019a. Inferring trophic groups of fish in the central-east Atlantic from eco-toxicological characterization. Chemosphere 229, 247-255. https://doi.org/https://doi.org/10.1016/j.chemosphere.2019.04.218.

Lozano-Bilbao, E., Díaz, Y., Lozano, G., Jurado-Ruzafa, A., Hardisson, A., Rubio, C., Jiménez, S., González-Weller, D. and Gutiérrez, Á.J., 2019b. Metal Content in Small Pelagic Fish in the North-West Africa. Thalassas 35, 643-653. https://doi.org/10.1007/ s41208-019-00141-7.

Lozano-Bilbao, E., Espinosa, J.M., Jurado-Ruzafa, A., Lozano, G., Hardisson, A., Rubio, C., GonzÁlez Weller, D. and Gutiérrez, Á.J., 2020a. Inferring Class of organisms in the Central-East Atlantic from eco-toxicological characterization. Reg. Stud. Mar. Sci. 35. https://doi.org/10.1016/j.rsma.2020.101190.

Lozano-Bilbao, E., Espinosa, J.M., Jurado-Ruzafa, A., Lozano, G., Hardisson, A., Rubio, C., Weller, D.G. and Gutiérrez, Á.J., 2020b. Inferring Class of organisms in the Central-East Atlantic from eco-toxicological characterization. Reg. Stud. Mar. Sci. https://doi. org/https://doi.org/10.1016/j.rsma.2020.101190.

Lozano-Bilbao, E., Espinosa, J.M., Lozano, G., Hardisson, A., Rubio, C., González-WeLLER, D. and Gutiérrez, Á.J., 2020c. Determination of metals in Anemonia sulcata (Pennant, 1777) as a pollution bioindicator. Environ. Sci. Pollut. Res. https://doi.org/10.1007/ s11356-020-08684-6.

lozano-Bilbao, E., Gutiérrez, Á.J., Hardisson, A., Rubio, C., González-Weller, D., Aguilar, N., Escánez, A., Espinosa, J.M., Canales, P. and Lozano, G., 2018b. Influence of the submarine volcanic eruption off El Hierro (Canary Islands) on the mesopelagic cephalopod's metal content. Mar. Pollut. Bull. 129, 474-479. https://doi.org/https://doi. org/10.1016/j.marpolbul.2017.10.017.

Lozano-Bilbao, E., Lozano, G., Jiménez, S., Jurado-Ruzafa, A., Hardisson, A., Rubio, C., Weller, D.G., Paz, S. and Gutiérrez, Á.J., 2020d. Ontogenic and seasonal variations of metal content in a small pelagic fish (Trachurus picturatus) in northwestern African 
waters. Mar. Pollut. Bull. 156, 111251. https://doi.org/https://doi.org/10.1016/j.marpolbul.2020.111251.

Mason, R.P., Laporte, J.-M. and Andres, S., 2000. Factors Controlling the Bioaccumulation of Mercury, Methylmercury, Arsenic, Selenium, and Cadmium by Freshwater Invertebrates and Fish. Arch. Environ. Contam. Toxicol.38, 283-297. https://doi.org/10.1007/s002449910038.

Naiche, L.A., Harrelson, Z., Kelly, R.G. and Papaioannou, V.E., 2005. T-Box Genes in Vertebrate Development. Annu. Rev. Genet. 39, 219-239. https://doi.org/10.1146/annurev. genet.39.073003.105925.

Pezzotti, G., McEntire, B.J., Bock, R., Boffelli, M., Zhu, W., Vitale, E., Puppulin, L., Adachi, T., Yамамото, T., Kanamura, N. and Bal, B.S., 2016. Silicon Nitride: A Synthetic Mineral for Vertebrate Biology. Sci. Rep. 6, 31717. https://doi.org/10.1038/srep31717.

Piatkowski, U., Vergani, D.F. and Stanganelli, Z.B., 2002. Changes in the cephalopod diet of southern elephant seal females at King George Island, during El Niño-La Niña events. J. Mar. Biol. Assoc. United Kingdom 82, 913-916. https://doi.org/DOI: 10.1017/ S0025315402006343.

Qing, X., Yutong, Z. and Shenggao, L., 2015. Assessment of heavy metal pollution and human health risk in urban soils of steel industrial city (Anshan), Liaoning, Northeast China. Ecotoxicol. Environ. Saf. 120, 377-385. https://doi.org/https://doi.org/10.1016/j. ecoenv.2015.06.019.

Raimundo, J., Pereira, P., Vale, C. and Caetano, M., 2005. Fe, Zn, Cu and Cd concentrations in the digestive gland and muscle tissues of Octopus vulgaris and Sepia officinalis from two coastal areas in Portugal. Ciencias Mar. 31, 243-251.

Rainbow, P.S. and Luoma, S.N., 2011. Metal toxicity, uptake and bioaccumulation in aquatic invertebrates-Modelling zinc in crustaceans. Aquat. Toxicol. 105, 455-465. https://doi. org/https://doi.org/10.1016/j.aquatox.2011.08.001.

Ratcliffe, N.A., Rowley, A.F., Fitzgerald, S.W. and Rhodes, C.P., 1985. "Invertebrate Immunity: Basic Concepts and Recent Advances," in Bourne, G.H.B.T.-I.R. of C. (ed.), . Academic Press, pp. 183-350. https://doi.org/https://doi.org/10.1016/S0074-7696(08)62351-7.

Roach, J.C., Glusman, G., Rowen, L., Kaur, A., Purcell, M.K., Smith, K.D., Hood, L.E. and Aderem, A., 2005. The evolution of vertebrate Toll-like receptors. Proc. Natl. Acad. Sci. USA. 102, 9577 LP - 9582. https://doi.org/10.1073/pnas.0502272102.

Ruilian, Y., Xing, Y., Zhao, Y., Hu, G. and Tu, X., 2008. Heavy metal pollution in intertidal sediments from Quanzhou Bay, China. J. Environ. Sci. 20, 664-669. https://doi.org/10.1016/ S1001-0742(08)62110-5.

SaÉnz de Rodrigáñez, M., Alarcón, F.J., Martínez, M.I. and Martínez, T.F., 2005. Caracterización de las proteasas digestivas del lenguado senegalés. X Congr. Nac. Acuic. 21, 21-22.

Schier, A.F., 2003. Nodal Signaling in Vertebrate Development. Annu. Rev. Cell Dev. Biol. 19, 589621. https://doi.org/10.1146/annurev.cellbio.19.041603.094522.

Storelli, M.M., Barone, G. and Marcotrigiano, G.O., 2005. Cadmium in Cephalopod Molluscs: Implications for Public Health. J. Food Prot. 68, 577-580. https://doi.org/10.4315/0362028X-68.3.577.

Storelli, M.M., Giacominelli-Stuffler, R., Storelli, A. and Marcotrigiano, G.O., 2006. Cadmium and mercury in cephalopod molluscs: Estimated weekly intake. Food Addit. Contam. 23, 25-30. https://doi.org/10.1080/02652030500242023. 
Sutton, M., Briggs, D.E.G., Siveter, D.J. and Siveter, D.J., 2001. Invertebrate evolution (Communications arising): Acaenoplax-polychaete or mollusc? Nature 414, 602+.

Tal, A.O., Finkelmeier, F., Filmann, N., Kylänpää, L., Udd, M., Parzanese, I., Cantù, P., Dechêne, A., Penndorf, V., Schnitzbauer, A., Friedrich-Rust, M., Zeuzem, S. and Albert, J.G., 2017. Multiple plastic stents versus covered metal stent for treatment of anastomotic biliary strictures after liver transplantation: a prospective, randomized, multicenter trial. Gastrointest. Endosc. 86, 1038-1045. https://doi.org/https://doi.org/10.1016/j. gie.2017.03.009. 